\title{
Hobbes on civic liberty and the rule of law
}

\author{
LARS VINX
}

Hobbes is often taken to have argued that we need to be willing to accept subjection to arbitrary sovereign power in order to enjoy social peace. In recent years, neo-republican authors like Philip Pettit and Quentin Skinner have adopted this reading and have used Hobbes as a foil against which to develop an account of the importance of the principle of nonarbitrary rule. I will show that Hobbes, far from providing the foil neorepublicans want, developed his own conception of non-arbitrariness, through his account of government according to law. This conception of non-arbitrariness differs in important respects from that put forward by neo-republican authors. But it might well provide a more plausible and realistic picture of the scope of the ideal of non-domination.

The chapter will proceed by examining Philip Pettit's perceptive account of Hobbes's theory of political freedom. Pettit has argued that Hobbes was concerned to defend two main claims about liberty. ${ }^{1}$ The first is the thesis that 'it is only the exercise of a power of interference that reduces people's freedom, not its (unexercised) existence - not even its existence in an arbitrary, unchecked form'. The second is the view that 'the exercise of a power of interference always reduces freedom in the same way, whether it occurs in a republican democracy, purportedly on a "non-arbitrary" basis, or under a dictatorial, arbitrary regime..

I will argue that it is doubtful whether these two theses can be attributed to Hobbes, and I will show that, to the extent that they can, they do not carry the implications Pettit associates with them. Hobbes was

The author would like to thank Olli Koistinen, Juha Räikkä, Simon Wigley and Bill Wringe for their helpful comments on draft versions of this chapter.

\footnotetext{
${ }^{1}$ See Philip Pettit, Republicanism. A Theory of Freedom and Government (Oxford University Press, 1997), 35-41 and Philip Pettit, 'Liberty and Leviathan' (2005) 4 Politics, Philosophy, and Economics 131. I will be concerned here with the more recent and more elaborate statement in 'Liberty and Leviathan'.

2 See Pettit, 'Liberty and Leviathan', 131, 148-149.
} 
concerned about the unexercised existence of powers capable of arbitrarily interfering with our freedom and he did not believe that a sovereign is free to exercise his authority in completely arbitrary ways. Rather, Hobbes developed a distinctive conception of civic liberty which expresses the demand that all political rule must abide by rule-of-law standards. The chapter analyses this conception of civic liberty through a comparison of the different forms of freedom discussed in Leviathan.

\section{Constitutional indifferentism and non-domination}

According to Pettit's neo-republican conception of political freedom, we are subject to domination, even while we are not experiencing any actual interference with our negative liberty, as long as we have to live under a power that could interfere, and do so arbitrarily, i.e. without having to give consideration to our legitimate interests. ${ }^{3}$ To be dominated is morally corrupting, for it forces us to 'bow and scrape ${ }^{\text {st }}$ in the face of superiors to prevent them from exercising their powers of arbitrary interference. Nondomination, non-subjection to powers of arbitrary interference, is therefore an essential prerequisite for enjoying the dignity and respect that is afforded to citizens but that is denied to mere subjects.

Hobbes, in Pettit's view, refuses to recognize non-domination as a distinct dimension of political freedom. ${ }^{5}$ Our interest in freedom, for Pettit's Hobbes, boils down to an interest in avoiding actual interference. According to the first thesis Pettit attributes to Hobbes, our subjection to a power of interference that would interfere arbitrarily if it were to interfere does not reduce our freedom as long as that power does not in fact interfere. Our interest in freedom therefore does not provide us with any reason to be concerned about the mere existence of an arbitrary power of interference. According to the second thesis, it does not matter whether a power interferes arbitrarily or non-arbitrarily if it interferes. The restriction of freedom that one suffers will be equally bad in either case. Our interest in freedom, therefore, does not provide us with any reason to prefer subjection to a non-arbitrary power to subjection to an arbitrary or dictatorial power. Hobbes's explicit support for constitutional indifferentism, the view that we have no deep reason to prefer one of the three

\footnotetext{
${ }^{3}$ See Pettit, Republicanism, 51-109.

${ }^{4}$ See ibid., 87.

${ }^{5}$ See ibid., 37-38; Pettit, 'Liberty and Leviathan', 148-149. See also Quentin Skinner, Liberty Before Liberalism (Cambridge University Press, 1998), 59-77; Quentin Skinner, Hobbes and Republican Liberty (Cambridge University Press, 2008), 138-177.
} 
constitutional forms (monarchy, aristocracy, democracy) to another, ${ }^{6}$ is taken by Pettit to confirm this interpretation.?

This account of Hobbes's constitutional indifferentism gets off on the wrong foot. Hobbes does not hold that we have no reason to prefer nonarbitrary to arbitrary, dictatorial rule. He claims, rather, that no form of government is in itself more or less arbitrary than any other. In Hobbes's view, any form of organized social control, in order to qualify as a form of political rule or of sovereignty, will have to be non-arbitrary in a number of morally important respects relating to the form in which public power is exercised. But no constitutional system, whether democratic or not, can guarantee that its subjects will never have to live with political decisions that they have reason to regard as unreasonable or unfair. ${ }^{8}$ The political decisions taken in a democracy will therefore not necessarily be less substantively arbitrary than those taken in a monarchy or aristocracy.

Note that constitutional indifferentism, so understood, does not entail that we have no reason to be interested in the difference between arbitrary and non-arbitrary forms of rule. It will lead us to that conclusion only once we identify one of the constitutional forms recognized by Hobbes, presumably democracy, with fully non-arbitrary and the others, like monarchy and aristocracy, with completely arbitrary or dictatorial rule. ${ }^{9}$ But of course, Hobbes never endorses this identification, and there are good reasons for avoiding it. A monarchy might clearly succeed in living up to the requirements of legal governance identified in Lon Fuller's internal morality of law..$^{10}$ Nor is there any reason to think that a democratic government could never act arbitrarily. Constitutional indifferentism, then, does not by itself conflict with the idea that any form of sovereign power, be it democratic, aristocratic or monarchic, will have to be non-arbitrary in some respects in order to qualify as an instance of political authority.

6 See Thomas Hobbes, Leviathan, edited by Richard Tuck (Cambridge University Press, 1991), 129-138.

7 See Pettit, 'Liberty and Leviathan', 145.

8 I will focus here on the first of these two elements of indifferentism. For discussion of the other see Lars Vinx, 'Constitutional Indifferentism and Republican Freedom' (2010) 38 Political Theory 809.

9 Pettit seems to attribute this view to Hobbes in 'Liberty and Leviathan', 132, where he claims that Hobbes persuaded later authors 'that the exercise of a power of interference always reduces freedom in the same way, whether it occurs in a republican democracy, purportedly on a "non-arbitrary" basis, or under a dictatorial, arbitrary regime'.

10 See Lon L. Fuller, The Morality of Law (New Haven: Yale University Press, rev. edn, 1964), 33-94. 
As has been pointed out by other authors, Hobbes puts surprising emphasis on developing an ideal of the rule of law. ${ }^{11}$ He evidently holds that some degree of respect for the ideal of the rule of law on the part of the sovereign is constitutive of the relationship between sovereign and subject (as opposed to the relationship between two enemies in a state of nature or the relationship of master and slave). And Hobbes's claim that any form of social control which is to count as a form of political rule will have to be non-arbitrary, in the sense of abiding by rule-of-law standards, stems precisely from his understanding of the nature of our interest in political freedom.

Pettit helpfully draws attention to the fact that Hobbes distinguishes between two different forms of freedom or liberty: liberty as nonobligation and liberty as non-obstruction. He also claims that these two are the only forms of freedom Hobbes recognizes. ${ }^{12}$ I believe that what Hobbes says about these two forms of freedom does not support the attribution of the two theses or of their purported implication - that we have no reason to be concerned with the danger of arbitrary rule - to Hobbes. It is wrong, moreover, that liberty as non-obstruction and liberty as nonobligation are the only two forms of freedom recognized by Hobbes. To defend these points, I will discuss liberty as non-obstruction in the second section of this chapter and liberty as non-obligation in the third section. The fourth section will deal with a third kind of liberty acknowledged by Hobbes, the liberty of subjects, and explain why it is distinct from the two forms of liberty Pettit recognizes in Hobbes.

\section{Hobbes on liberty as non-obstruction}

Liberty as non-obstruction is a body's freedom to move around unimpeded by external physical obstacles. A body is free, Hobbes claims, as long as its local movement is not blocked or obstructed..$^{13}$ Liberty

11 See David Dyzenhaus, 'Hobbes and the Legitimacy of Law' (2001) 20 Law and Philosophy 461; Noel Malcolm, 'Hobbes's Theory of International Relations', in Noel Malcolm, Aspects of Hobbes (Oxford University Press, 2002), 432.

${ }^{12}$ Pettit, 'Liberty and Leviathan', 139.

${ }^{13}$ Hobbes, Leviathan, 145-146: 'Liberty, or Freedome, signifieth (properly) the absence of Opposition; (by Opposition I mean externall Impediments of motion;) and may be applyed no lesse to Irrationall, and Inanimate creatures, than to Rationall. For whatsoever is so tyed, or environed, as it cannot move, but within a certain space, which space is determined by the opposition of some externall body, we say it hath not Liberty to go further. And so of all living creatures, whilest they are imprisoned, or restrained, with walls, or chains; and of the water whilest it is kept in banks, or vessels, that otherwise 
as non-obstruction, then, has a very wide sphere of application. It can be attributed to rational and irrational creatures or even to inanimate physical objects. To cite one of Hobbes's examples: the liberty of the water in my mug is restricted by the wall of the mug, since the water would otherwise flow down. Likewise, Hobbes argues, the liberty of an animate creature is restricted if it is imprisoned, walled in, or put in chains. ${ }^{14}$

Hobbes's conception of liberty as non-obstruction is beset by an ambiguity that arises from the fact that the movement of animate creatures, including human beings, causally depends on their desires and on their beliefs about the external environment. Hobbes expresses this fact by saying that the external movement of animals is voluntary, that it proceeds from their own will, which is in turn defined as the last appetite in deliberation that immediately precedes action. ${ }^{15}$ Needless to say, an animal's will, as formed by deliberation, will often reflect the animal's perception of external obstacles to motion. A prudent and experienced animal will avoid movement likely to bring it into collision with an external obstacle. The ambiguity in Hobbes's definition of liberty as non-obstruction concerns the question whether an animal that so adapts to external obstacles can be said to suffer a restriction of its liberty.

According to the reading of Hobbes's definition of liberty adopted by Pettit, we may call it the actualist reading, an external obstacle restricts my freedom only if it actually interrupts some voluntary motion of mine, i.e. only if I have decided to act in a certain way, have embarked upon the chosen course of action, and then find my movement frustrated by an external impediment. ${ }^{16}$ According to this understanding of liberty as non-obstruction, my liberty will not be obstructed by some obstacle if I never form the will, in Hobbes's technical sense of the term, to do what the obstacle would prevent me from doing. And this result holds despite the fact that my deliberative processes are conditioned by my knowledge of the existence of the obstacle, even if I would form a will to act in the way the obstacle prevents me from acting if the obstacle didn't exist. This interpretation, Pettit points out, seems to fit well with Hobbes's definition of a 'free man' as 'he, that in those things which by

\footnotetext{
would spread it selfe into a larger space, we use to say, they are not at Liberty, to move in such a manner, as without those externall impediments they would.'

${ }^{14}$ See ibid., 145-146.

15 See ibid., 37-38, 44-45.

${ }^{16}$ See Pettit, 'Liberty and Leviathan', 137-139.
} 
his strength and wit he is able to do, is not hindred to do what he has a will to do.' ${ }^{17}$

Now clearly, this view of liberty as non-obstruction implies patently absurd consequences. It entails that I might enjoy complete freedom of non-obstruction even while being imprisoned in a windowless cell in the bowels of Alcatraz with my feet in thick chains. According to the actualist reading, I am suffering a restriction of liberty only as long as I make an actual attempt to break out of my cell. As soon as I stop hammering the walls with my bare fists, in recognition of the obvious fact that I won't be able to break them down, I am free, no matter how intensely I desire to get out of my cell. I am free since I no longer have the will (in Hobbes's technical sense of the term) to escape. The actualist interpretation, I conclude, openly contradicts Hobbes's official definition of liberty, which claims that a human being that is imprisoned, or restrained, with walls, or chains' suffers a restriction or loss of its liberty as non-obstruction. ${ }^{18}$ As charitable readers, we therefore have reason to reject it if there is another interpretation that is exegetically defensible. ${ }^{19}$

One obvious alternative interpretation is to take Hobbes's definition of liberty to say that an agent is free to $\phi$ if and only if he is internally capable of $\phi$-ing and no external impediment would prevent him from $\phi$-ing if he were to form the will to $\phi$. Since I am taken to suffer a restriction of

17 Hobbes, Leviathan, 146. Pettit also points to a passage in the Questions Concerning Liberty, Necessity, and Chance in English Works of Thomas Hobbes, edited by William Molesworth, vol. V (London: John Boon, 1841), 351-352 to support the actualist reading. Hobbes discusses a scenario where someone deliberates whether to play tennis or not, not knowing that the door to the tennis court is locked, so that he won't be able to play should he decide to do so. Bramhall had used this example to argue that there is an inconsistency between Hobbes's claim that a man is free 'that hath not yet made an end of deliberating' and his claim that liberty is 'an absence of outward impediments': if liberty is an absence of outward impediments, then the man is not a free man since he is not at liberty to play tennis, which contradicts the claim that he must be free because he is still deliberating. Hobbes responds that 'it is no impediment to him that the door is shut, till he have a will to play; which he hath not till he hath done deliberating whether he shall play or not'. This reply seems to lend support to Pettit's actualist reading. However, the scenario assumes that the man doesn't know that the door is locked. Hence, it is unclear what Hobbes would have said about a scenario where the man desires to play tennis, and would form a will to do so, if it weren't for his knowing that the door is locked. I am therefore disinclined to regard the passage as decisive evidence for the actualist interpretation.

${ }_{18}$ Hobbes, Leviathan, 145-146.

19 In a recent paper, Pettit acknowledges the absurdity of the actualist view, but nevertheless continues to attribute it to Hobbes, as though it didn't matter that the attribution conflicts with Hobbes's definition of liberty. See Philip Pettit, 'The Instability of Freedom as Noninterference: The Case of Isaiah Berlin' (2011) 121 Ethics 693, 699-701. 
liberty whenever there is an obstacle that bars me from doing something that it would be in my power to do if it weren't for the obstacle, we can no longer infer that prisoners are free once they cease to try to escape, in recognition of the futility of the attempt. Another alternative interpretation that would likewise allow us to avoid the embarrassing implications of the actualist view, and that is perhaps closer in line with the text, holds that my freedom is restricted if and only if one of the following two conditions is met: either an action I have chosen to perform is obstructed by an external obstacle; or my awareness of an external obstacle stops me from forming the will to do something that I would choose to do if it weren't for my awareness of the obstacle. ${ }^{20}$ Under this view, my freedom is not restricted by obstacles that would prevent me from doing things that I do not wish to do. But under the plausible assumption that those who are imprisoned or in chains typically wish not to be so constrained, we will still be able to save Hobbes's claim that prisoners or slaves suffer a restriction of liberty of non-obstruction.

The only textual passage in Leviathan that seems to favour the actualist reading over these alternatives is the definition of the free man, since it explicitly claims that we lack liberty only if we are blocked from doing what we have a will to do. However, to say that a free man is a man who is not hindered to do what he has a will to do might, in this context, be a shorthand way of saying that I am free to $\phi$ if I would not encounter an obstacle if I were to form the will to $\phi$. It might be a way, alternatively, of expressing the point that someone who is not imprisoned, in chains, or under someone else's direct physical control will usually not encounter external obstacles in doing what he wishes to do. ${ }^{21}$

As I pointed out above, Pettit adopts the actualist interpretation of liberty as non-obstruction. He also holds that it entails that there is no reason to be concerned with the mere existence of a power of arbitrary

${ }^{20}$ Hobbes frequently suggests that our freedom is not restricted if an obstacle blocks actions that we do not desire to perform. In Hobbes, Leviathan, 146 he speaks of 'the Liberty of the man; which consisteth in this, that he finds no stop, in doing what he has the will, desire, or inclination to doe'. In the context of the tennis example, Hobbes explains: 'nor can any man be said to be hindered from doing that, which he had no purpose at all to do' (Hobbes, Questions Concerning Liberty, Necessity, and Chance, 352). On the plausible assumption that having a desire or inclination to $\varphi$ is not the same thing, for Hobbes, as having a will (in Hobbes's technical sense of the term) to $\phi$, these passages speak against the actualist reading.

${ }^{21}$ Hobbes repeatedly draws a simple contrast between people who are free to move about at will and those who have lost their freedom of movement since they are imprisoned or in chains. See Hobbes, Leviathan, 141, 147. 
interference, a claim I do not wish to dispute. After all, it is hard to see why one should be concerned about the mere existence of a power of arbitrary interference if one is taken to be perfectly free until one literally runs up against a physical obstacle. If Matthew Kramer is right to argue that we can always choose to refrain from actively resisting a physical obstacle ${ }^{22}$ the actualist interpretation will imply that we can always choose to be perfectly free, regardless of what others are doing to us. Why bother, in that case, with the existence of a power capable of arbitrary interference?

But how does the view that Hobbes is unconcerned with arbitrary rule hold up if we adopt one of the alternative and less absurd interpretations of liberty as non-obstruction? At first glance, the switch might seem to make little difference. Even if we agree that one of the alternative interpretations must be correct, it will still be the case that it is only the actual exercise of a power of physical interference, not its mere existence, which can reduce our freedom of movement. It still holds true, moreover, that a reduction of our freedom of movement will be equally bad regardless of how it comes about. A reduction of liberty of non-obstruction that is undesirable for the person who suffers it, insofar as it stops her from doing something she wishes to do or might come to wish to do, is not made any better by the fact that it results from a non-arbitrary interference. What I would like to argue, nevertheless, is that it doesn't follow from these observations, however true, that a Hobbesian interest in liberty as nonobstruction provides us with no reason to care whether we are subject to an arbitrary or a non-arbitrary power of interference.

Hobbes holds that the obstruction of their movement must be the prime evil for human beings. According to Hobbes's view of the good, our supreme interest is to live, and to live contentedly, for as long as possible. ${ }^{23}$ And life, according to Hobbes, is nothing but continuous internal vital motion; a motion that is dependent on external resources that humans can only obtain through unimpeded external and voluntary motion. ${ }^{24}$ Actual collision with other human beings, or physical confinement within a very narrow space at their hands, is not just inconvenient. It is typically inimical to the preservation of our life. We therefore have an overriding interest in avoiding such collision or confinement, to be able to perform such movements as are necessary for us to live and to live contentedly. ${ }^{25}$

\footnotetext{
22 See Matthew Kramer, The Quality of Freedom (Oxford University Press, 2003), 17-20.

${ }^{23}$ Hobbes, Leviathan, 69-70.

${ }^{24}$ See ibid., 37-40.

25 That non-obstruction is our primary interest explains why Hobbes claims that nonobstruction is the proper signification of liberty. See ibid., 91, 145.
} 
Individual adaptive behaviour, in the state of nature, cannot reliably avoid obstruction at the hands of others. In the state of nature it is not in my own power, due to the unpredictability of the behaviour of others, to ensure that I will avoid potentially lethal or confining conflict. While moving around trying to procure the external resources I need to sustain my internal motion, I am very likely to find myself in situations, through no fault of my own, where I am forced to fight with others, and to hazard my life and my physical liberty on the guess that I will be strong enough to prevail. ${ }^{26}$ In the state of nature I am threatened by everyone else's possession of a 'Right to every thing; even to one anothers body'. ${ }^{27}$ This right is clearly an arbitrary power in Pettit's sense, ${ }^{28}$ and Hobbes quite obviously thinks that we have to be concerned about the mere existence of that power in someone else's hands, even if we have not so far suffered any loss of liberty of non-obstruction from any actual exercise of that right. ${ }^{29}$

Our fundamental aim, Hobbes concludes, should be to put ourselves into a condition that makes it possible for us unilaterally to avoid collision with others or obstruction at their hands, while enjoying enough freedom of movement to maintain our life and to live contentedly. The crux of Hobbes's argument for civil society is that unilateral avoidance of physically obstructing conflict will become possible in civil society. Civil society provides the assurance that I will very likely be able to continue to move around unobstructedly, while doing what is necessary to satisfy my interest in survival and contentment, as long as I obey its laws.

The obvious reply for Pettit to make to this line of reasoning is to admit that Hobbes was concerned about the mere existence of private powers of arbitrary interference, but that he did not think we should be concerned about the mere existence of governmental powers of arbitrary interference. This reply overlooks that civil society, if it is to allow us unilaterally to avoid obstructing conflict, cannot take the form of an arbitrary dictatorship. In order to provide us with a reliable idea of what kinds of actions we will be able to perform without having to face interference by others, the sovereign will have to govern his subjects through a system of laws and not in a purely discretionary fashion. People must be in a position to know what rules to follow in order to have assurance that they will not

\footnotetext{
26 See ibid., 86-90. ${ }^{27}$ Ibid., 91.

28 See Pettit, Republicanism, 52-58.

29 Hobbes, Leviathan, 147, in a revealing turn of phrase, calls the right of nature the liberty 'by which all other men may be masters of their lives'.
} 
find themselves caught up in physically obstructing conflict. ${ }^{30}$ Laws, to fulfil this function, will have to exhibit the features which theorists of the rule of law associate with legal governance: they will have to be public, prospective, sufficiently clear, and consistent with each other, they must not demand the impossible, and so on. ${ }^{31}$

Of course, compliance with law will allow me to avoid collision or confinement only if I can expect others to comply as well. This expectation cannot be wholly based on the sovereign's power to sanction transgressions of the law. The sovereign cannot credibly threaten all of us, or a majority of us, at the same time. The standard motive for obedience, then, will have to be some form of shared insight into the reasonableness of mutual compliance with the law. ${ }^{32}$ This is why Hobbes strives to show that it is rational to obey the laws, even apart from any consideration of the threat of incurring a legal sanction, if others can be counted upon to do the same. ${ }^{33}$ While this insight is unlikely to be perfectly effective, due to the influence of passion and irrationality, it will at least have to be available to all of us, which is another way of saying that it must be possible to see the laws as serving everyone's interest and as serving it equally. ${ }^{34}$

Finally, the idea of legal governance implies that the sovereign himself will treat his subjects in accordance with principles of legality. ${ }^{35}$ To be authoritative, a sovereign's demands must be expressed in legal form and

${ }^{30}$ Ibid., 231 Hobbes claims that sovereigns should govern 'by a generall Providence, contained in publique Instruction ... and in the making, and executing of good Lawes, to which individuall persons may apply their own cases'. Also ibid., 239-240: 'For the use of Lawes ... is not to bind the People from all Voluntary actions; but to direct and keep them in such a motion, as not to hurt themselves by their own impetuous desires, rashnesse, or indiscretion; as Hedges are set, not to stop Travellers, but to keep them in the way.'

31 See ibid., 214-219, 239-241.

32 Hobbes consequently argues $i b i d ., 232$ that his views on sovereignty 'have the rather need to be diligently, and truly taught; because they cannot be maintained by any Civill Law, or terrour of legall punishment'.

33 See ibid., 96-97, 101-103.

${ }^{34}$ Ibid., 108: 'if a man be trusted to judge between man and man, it is precept of the Law of Nature, that he deale Equally between them'. Hobbes consequently demands 'that Justice be equally administred to all degrees of People; that is, that as well the rich, and mighty, as poor and obscure persons, may be righted of the injuries done them; so as the great, may have no greater hope of impunity, when they doe violence, dishonour, or any Injury to the meaner sort, then when one of these, does the like to one of them' (ibid., 237).

35 This requirement does not rule out that a sovereign might, in cases of open rebellion, choose to treat a person as an enemy. But of course, a person so treated will no longer be a subject or have duties of obedience to sovereign authority. See ibid., 216, 219. 
be applied through the legal system. ${ }^{36}$ Most importantly, subjects must have assurance that - as long as they do not rebel - the sovereign is not going to deprive them of their freedom of movement unless they have been found, in a fair trial, to have violated a known law. If the point of subjection to the laws is to put one in a position unilaterally to avoid collision and confinement, then the sovereign must refrain from using obstructing violence against his subjects in any other way than by punishing them for acknowledged breaches of known laws. ${ }^{37}$

The observation that sovereign authority must treat its subjects in lawful ways provides a reply to Pettit's basic claim that Hobbes was uninterested in the distinction between arbitrary and non-arbitrary rule. Sovereign authority must be non-arbitrary in a number of crucial respects since it would otherwise fail to allow us unilaterally to avoid physical collision with others or confinement at their hands, and safely to do what we need to do to survive and to live contentedly. Our interest in liberty of nonobstruction thus requires a government committed to the rule of law. In Hobbes's view, this is a claim about the nature of all government that applies regardless of constitutional form. It never makes sense, hence, to distinguish between arbitrary and non-arbitrary government. But it does not follow that Hobbes was uninterested in the distinction between arbitrary and non-arbitrary forms of social control.

\section{Hobbes on liberty as non-obligation}

Let us now come to the second understanding of liberty Pettit attributes to Hobbes. Liberty as non-obligation consists in 'one's freedom to choose between certain alternatives, uncommitted by prior ... obligation'. ${ }^{38}$ In the state of nature, we are typically free of all obligation, due to 'the liberty each man has, to use his own power, as he will himselfe, for the preservation of his own nature'. ${ }^{39}$ Here, my actions depend exclusively on my own present will. I am not subject to anyone else's command and I am not bound to intentions that I may have formed or even declared in the past. Freedom as non-obligation can be lost only through the making of contracts by which one binds oneself to another. The most important of

\footnotetext{
36 In a case of controversy with the sovereign, a subject 'hath the same Liberty to sue for his right, as if it were against a Subject' if the sovereign's claims are 'grounded on a precedent Law' (ibid., 152-153).

37 See the discussion of punishment, ibid., 214-219.

38 See Pettit, 'Liberty and Leviathan', 133-137.

39 Hobbes, Leviathan, 91.
} 
these contracts, of course, is the social contract, in which we give up our freedom to use our own power as we see fit to the sovereign, and thus bind ourselves to obey the sovereign's laws.

Pettit is certainly correct in pointing out that Hobbes recognizes freedom of non-obligation as a category of freedom distinct from nonobstruction. According to Hobbes, one can enjoy freedom of non-obligation, for example as a slave or prisoner of war, while finding one's freedom of movement obstructed. ${ }^{40}$ On the other hand, where one is obligated, as a subject of a sovereign's laws, one will typically not be obstructed from violating one's legal obligations, though one must expect to face punishment should one decide to break the law. ${ }^{41}$

In Pettit's view, however, the acknowledgement of freedom of nonobligation does not soften Hobbes's attitude towards the problem of domination. Pettit argues that the two theses apply to freedom of non-obligation in exactly the same way they apply to freedom of non-obstruction. Hence, our interest in freedom as non-obligation, like our interest in freedom as non-obstruction, does not, according to Pettit's Hobbes, provide us with a reason to prefer non-arbitrary government. ${ }^{42}$ What is more, the fact that subjection to the law will usually go along with possession of freedom as non-obstruction does not ease the burden of subjection in any meaningful way. According to Pettit, Hobbes held that people who are subject to physical chains or imprisonment and people who are tied by legal bonds 'are equally unfree', and that the commonwealth may therefore treat its subjects in just the same way as slaves without forfeiting its authority over them. ${ }^{43}$

Pettit's account of freedom of non-obligation and its relation to political power is mistaken on two counts. The first has to do with Pettit's understanding of freedom as non-obligation. Upon entry into civil society, Pettit assumes, our freedom of non-obligation is not altogether given up but merely restricted. Even in civil society, we retain a residue of liberty as non-obligation: the liberty to decide for ourselves where the laws are silent which Hobbes calls the liberty of a subject. ${ }^{44}$ The possession of

40 See ibid., 141.

41 See ibid., 146-147. Also Quentin Skinner, 'Hobbes on the Proper Signification of Liberty', in Quentin Skinner, Visions of Politics, Volume III: Hobbes and Civil Science (Cambridge University Press, 2002), 209, 210-225.

42 See Pettit, 'Liberty and Leviathan', 148.

43 Ibid., 141, 145.

44 See Pettit, 'Liberty and Leviathan', 144. See also Skinner, 'Hobbes on the Proper Signification of Liberty', 233. 
this residual freedom of non-obligation is clearly desirable, and since the residue may be smaller or larger, depending on how the sovereign chooses to exercise his legislative powers, it is desirable that the sovereign interfere as little as possible with it. Once we accept this picture of liberty as nonobligation, it is not hard to see how the two theses would apply to liberty as non-obligation. The mere unexercised existence of a governmental power entitled arbitrarily to restrict our residual freedom as non-obligation does not in fact restrict that freedom, and if that freedom is restricted, the restriction will be equally bad regardless of whether it came about arbitrarily or non-arbitrarily.

One clear exegetical reason to think that this must be an inaccurate portrayal of Hobbes's views is provided by the way Hobbes introduces the liberty of subjects in chapter 21 of Leviathan.$^{45}$ Hobbes declares that, in the rest of the chapter, he will speak exclusively about the liberty of subjects, and not about two other forms of freedom: the liberty of nonobstruction, which people so manifestly possess as law-abiding subjects of a sovereign, and the liberty that is an 'exemption from Lawes', a liberty 'by which all other men may be masters of their lives'. ${ }^{46}$ The implication of this passage is clearly that there are three forms of freedom, but that it is not necessary to discuss the latter two after the commonwealth has been established, since people evidently possess the first of these latter two freedoms, as subjects of a sovereign, while they shouldn't at all want to have the second. That second freedom people shouldn't want to possess, the exemption from laws, can only be the complete freedom from obligation we enjoy in the state of nature. People shouldn't want to possess it because it entails a right to all things that permits everyone to kill or enslave everyone else. Hobbes's suggestion here must be that this natural form of non-obligation cannot be enjoyed within civil society. ${ }^{47}$ But if this

45 Hobbes, Leviathan, 147: 'In relation to these Bonds [legal obligations, L.V.] only it is, that I am to speak now, of the Liberty of Subjects ... For if wee take Liberty in the proper sense, for corporeall Liberty; that is to say, freedome from chains, and prison, it were very absurd for men to clamor as they doe, for the Liberty they so manifestly enjoy. Againe, if we take Liberty, for an exemption from the Lawes, it is no lesse absurd, for men to demand as they doe, that Liberty, by which all other men may be masters of their lives.'

46 Ibid., 147.

47 See ibid., 200: 'But Civill Law is an Obligation; and takes from us the Liberty which the Law of Nature gave us. Nature gave a Right to every man to secure himselfe by his own strength, and to invade a suspected neighbour, by way of prevention: but the Civill Law takes away that Liberty, in all cases where the protection of the Law may be safely stayd for.' Admittedly, Hobbes sometimes slips into language that suggests a residual natural freedom. See for instance ibid., 185. 
is the case, the liberty of subjects, what we might call civil non-obligation, cannot be a simple residue of the natural freedom of non-obligation. It must be a different kind of freedom.

This point can also be defended on a systematic basis. Hobbes argues that it is impossible for us to incur any partial normative commitment of mutual trust to another private person without taking on a prior commitment of (almost) unconditional obedience to the sovereign. ${ }^{48}$ Natural liberty as non-commitment, then, cannot be partially abdicated. As long as there is no sovereign, all individuals fully retain it. Once we are subject to a sovereign, by contrast, we retain none of it. ${ }^{49}$ The liberty of subjects cannot be construed as a simple absence of obligation or an exemption from the laws. Rather, it is of the nature of an implicit permission. We enjoy the freedom of the subject at the sufferance of the sovereign who has chosen not to exercise his legislative power in a certain area, but who is entitled to modify or further restrict our sphere of freedom without our renewed consent..$^{50}$ It is wrong, then, to think of the liberty of a subject as a residue of our natural freedom as non-obligation.

If we have to distinguish between two different forms of non-obligation, we must inquire separately into how each relates to Pettit's two theses. Since I will return to the liberty of subjects in the next section, I will focus on natural non-obligation for now. As far as natural non-obligation is concerned, it should be clear that Pettit's two theses do not apply to it. If natural non-obligation can only be retained or be given up altogether, and if we ought to give it up to avail ourselves of the benefits of civil society, it simply makes no sense to think of natural non-obligation as a freedom that we should have an interest to keep. Nor does it make sense to think of it as a freedom that could be possessed to larger or lesser degree, depending on how a government chooses to exercise its powers.

This, however, is not the only thing that is wrong with Pettit's analysis of the natural freedom of non-obligation. Hobbes did not take the view that people who are subject to legal bonds are as unfree as people who are enslaved or imprisoned by physical obstacles. To see why this parallel is

48 See ibid., 96.

49 Hobbes claims, of course, that there are 'some Rights, which no man can be understood by any words ... to have abandoned, or transferred' (ibid., 93), such as the right to defend oneself against attack or to resist 'Wounds, and Chayns, and Imprisonment'. But these reservations will only apply where a sovereign and a former subject have already reentered a state of war. They do not constitute limitations internal to the relationship of subject to sovereign and should therefore not be confused with a liberty that a subject enjoys under the laws of the sovereign.

50 See ibid., 152. 
misleading is also to see why our natural freedom of non-obligation can only be given up to a power that is in important respects non-arbitrary.

In the context of his discussion of the right of conquest in Leviathan, Hobbes draws a clear distinction between servants or subjects and slaves. He explains that 'by the word Servant ... is not meant a Captive, which is kept in prison, or bonds'. Rather, a servant is someone who 'being taken, hath corporall liberty allowed him; and upon promise not to run away, nor to do violence to his Master, is trusted by him..${ }^{51}$ Consequently, Hobbes emphasizes that it is not the fact of victory that gives the conqueror authority, but rather the voluntary subjection of the vanquished. ${ }^{52}$

This passage is difficult to square with Pettit's interpretation of Hobbes's discussion of the right of conquest. In Pettit's view, this discussion implies that a Hobbesian government has 'the same dominion over individuals that would hold if it constrained them by physical or corporal means. ${ }^{33}$ But this must be wrong, at least if it is taken to mean that a Hobbesian government can treat its subjects in just the same way as slaves without forfeiting its authority over them. The corporal liberty that Hobbes claims is granted to the servant, but not to the slave, must be a liberty that will not be taken away arbitrarily, without due process of law. Otherwise, the subject would have to continue to consider the conqueror an enemy, and to make use of the first opportunity to kill or overpower him. In making a promise of submission in exchange for corporal liberty, the vanquished gives up the natural right to try to kill or overpower the conqueror. Hobbes holds that we cannot enter into a valid contract without receiving a sufficiently valuable return for the rights that we transfer or lay down. ${ }^{54}$ And it is hard to see how this condition could be fulfilled if the conqueror tried to reserve to himself the right to kill or imprison his new subject on completely arbitrary grounds. If obedience did not assure protection against a renewed attack on the part of the conqueror, the subject's chances of self-preservation couldn't possibly benefit from giving up the right to make war against the conqueror. ${ }^{55}$ Hence, even a

51 Ibid., 141. $\quad{ }^{52}$ Ibid.

53 Pettit, 'Liberty and Leviathan', 145.

54 Hobbes, Leviathan, 93.

55 It might be objected that Hobbes denies that the relationship between sovereign and subject can be contractual. However, Hobbes explicitly claims that a commonwealth by acquisition is based on a covenant between the conqueror and the conquered. Hobbes, Leviathan, 141: 'And this Dominion is then acquired to the Victor, when the Vanquished, to avoid the present stroke of death, covenanteth either in expresse words, or by sufficient signes of the Will, that so long as his life, and the liberty of his body is allowed him, the 
conqueror must be willing to offer governance by law to those he intends to make his subjects. ${ }^{56}$

I conclude that Pettit is wrong to attribute to Hobbes the view that it does not matter whether our liberty is restricted by a physical obstacle or by a sanction-backed law. Hobbes was perfectly aware that physical obstruction and lawmaking can't be equivalent means of social control, since he acknowledges that it will sometimes be impossible for a ruler to achieve through the latter what he can achieve through the former. ${ }^{57}$ Lawmaking, or the attempt to provide behavioural guidance through the issuance of authoritative rules, can be successful only if people are treated in accordance with rule-of-law standards, and are thus given a reason to prefer voluntary compliance with a sovereign's directives to the state of nature and to war against the sovereign. Hobbes's awareness of this point explains why he is very careful to distinguish, in Leviathan at least, between subjects and slaves, and why he holds that to treat a subject like a slave, by unlawfully detaining or assaulting the subject, is an act of hostility that severs the bond of civic subjection..$^{58}$ Hobbes, in sum, held that it cannot be reasonable for people to give up their natural freedom of non-obligation to a power altogether arbitrary.

\section{Hobbes on the liberty of a subject}

Hobbes defines the liberty of the subject as the freedom of subjects 'of doing what their own reason shall suggest, for the most profitable of

Victor shall have the use thereof, at his pleasure.' Whether this introduces inconsistency into Hobbes's theory of sovereignty is an issue that I cannot settle here.

${ }^{56}$ In De Cive Hobbes describes servants and subjects as different kinds of slaves, as Pettit points out. But he draws essentially the same distinction between subjection and physical slavery we find in Leviathan: 'The obligation, therefore, of a slave to a Master does not arise simply because he spared his life but because he does not keep him bound or in prison. For an obligation arises from agreement, and there is no agreement without trust ... Hence in addition to the benefit of sparing his life there is also the trust by which the Master leaves him in physical liberty, so that he could not only run away but could even take the life of the Master who saved his, if it were not for the obligation and bonds of agreement between them' (Thomas Hobbes, On the Citizen, edited by Richard Tuck and Michael Silverthorne (Cambridge University Press, 1997), 103). Hobbes claims a little later on that a 'Master therefore has no less right and dominion over the unbound slave than over the bound' (ibid., 104). But in this passage Hobbes is clearly concerned to argue that the sovereign is entitled to interfere with property-rights without the subject's consent, not to deny that he is bound to rule-of-law standards.

57 See Hobbes, Leviathan, 98.

${ }^{58}$ See ibid., 93, 214-219. 
themselves' in 'all kinds of actions, by the laws praetermitted'. ${ }^{59}$ It might seem at first glance that the liberty of a subject must be either a freedom of non-obstruction, a residue of the natural freedom of non-obligation, or some combination of both. But this view is false and it is therefore wrong to claim that freedom as non-obstruction and freedom as non-commitment are the only two freedoms recognized by Hobbes.

I already explained why the liberty of a subject cannot be understood as a residue of the natural freedom of non-obligation. The liberty of the subject is equally irreducible to the freedom of non-obstruction, since the latter is normally more encompassing than the former. In civil society, we do, after all, have the liberty of non-obstruction to commit crimes, ${ }^{60}$ though it is likely that we will be punished for criminal acts. For me to have the liberty of a subject to $\phi$ it is not sufficient, hence, that I enjoy the liberty of non-obstruction to $\phi$. It is not necessary either, since another person might unrightfully block me from $\phi$-ing though I have the liberty of a subject to $\phi$.

What it means for me to have the liberty of a subject to $\phi$ is that the state is committed to using its force to protect my opportunity to $\phi$ without facing an impediment. In a well-functioning state I am unlikely to see actions that fall within my liberty as a subject frustrated by the obstruction of others. Others who might want to obstruct actions that I am legally entitled to perform are liable to punishment if they obstruct me and are thus likely to be deterred from interfering with my actions (as well as from threatening to interfere). As a result, I can reliably expect that actions I am legally entitled to perform will not face external obstruction. Moreover, since the sovereign and his representatives will apply punishments only consequent upon prior breach of known laws, by complying with the law I am in a position to avoid collision with the state's coercive power.

Are Pettit's two theses applicable to the liberty of a subject? It is of course true that the liberty of a subject will only be restricted through actual exercises of legislative power. And we may grant as well that a loss of a certain amount of the liberty of a subject is always in itself bad for the persons concerned. But it does not follow that our interest in the liberty of a subject provides us with no reason to prefer non-arbitrary to arbitrary governance. The liberty of a subject can exist only in the context of a system of legal governance, which, as we have seen, implies that the exercise of political power is non-arbitrary in important respects. Hobbes makes it clear that any attempt on the part of the government to obstruct

\footnotetext{
59 Ibid., 147. ${ }^{60}$ See ibid., 146-147.
} 
me from doing something that I have the liberty of a subject to do, or any attempt to sanction me for having done something that it was in my liberty of a subject to do, is an act of hostility that severs the bond of subjection between citizen and sovereign. ${ }^{61}$ My liberty of a subject can only be conditioned and modified through public and prospective legislation and impartial adjudication.

The liberty of a subject, moreover, sheds an interesting light on another of Pettit's claims about Hobbes's understanding of freedom. Pettit argues that Hobbes does not recognize the idea of freedom as non-coercion (i.e. the idea of a freedom from threats of coercion that stop me from forming a will to do what I wish to do). ${ }^{62}$ It is true that Hobbes holds that a mere threat of coercion never takes away the freedom of non-obstruction. It is also true that, for Hobbes, a threat of coercion doesn't take away freedom of non-obligation, as only a contract can abrogate that freedom. But since Hobbes acknowledges a third form of liberty over and above natural nonobligation and physical non-obstruction, these observations do not imply that he fails to recognize freedom of non-coercion or that he doesn't hold it to be valuable. The liberty of a subject, after all, clearly is a freedom of non-coercion.

On the condition that the state is doing its job well, I can expect not to be subject to threats of coercion issuing from other private individuals. Of course, the liberty of a subject is not a complete freedom from coercion, as the state will continue to use threats of coercion to deter me from performing acts it has declared to be illegal. But as we have seen, natural non-obligation can only be alienated to, and civil non-obligation can only be provided by and conditioned by, a sovereign power that governs in accordance with the rule of law and that we have sufficient reason to support apart from its threats of coercion. Hobbes is therefore in a position to claim that we do not lack any freedom from coercion that we ought to possess.

\section{Conclusion: the neo-republican critique of Hobbes}

Let me ward off a possible misunderstanding of the argument I have presented. I am not denying that there are important differences between the rule-of-law based understanding of non-arbitrariness I have attributed to

61 See ibid., 214-219.

62 See Pettit, 'Liberty and Leviathan', 146-148; see also Skinner, 'Hobbes on the Proper Signification of Liberty', 232-237. 
Hobbes and the neo-republican conception of non-domination. Hobbes's conception of the rule of law does not promise to create a polity that will fully realize the ideal of non-domination as Pettit understands it. ${ }^{63}$ The rule of law will not give me assurance that my will is never going to be bent to laws that I judge to violate the public interest, it does not require that legislative decisions be taken democratically, and it does not imply that every public decision must be endlessly contestable. All I have argued is that Hobbes wasn't unconcerned with the problem of arbitrary power. But of course, his solution may strike the republican as too thin and undemanding to be very interesting.

Whether this would be an appropriate republican response is a question I cannot definitively answer here. However, it does seem to me that neo-republicans tend not to take Hobbes's views seriously enough as a possible alternative to their own conception of non-arbitrariness.

Neo-republicans assume that Hobbes started from the aim to defend constitutional indifferentism. They take it that this is tantamount to the aim of defending arbitrary government, and then go on to argue that Hobbes's conception of liberty must have been a mere rationalization of this prior commitment. ${ }^{64}$ This rationalization, to be successful, or so the story goes, had to define away the idea of freedom as non-domination, which forced Hobbes to invent out of whole cloth a novel conception of liberty, one that is clearly less attractive than the republican ideal of freedom. ${ }^{65}$ Neo-republicans portray Hobbes as having been immensely successful in his endeavour to make people forget the ideal of freedom as non-domination. ${ }^{66}$ But they never quite explain why Hobbes's redefinition of liberty should have been so influential, given that it is allegedly little more than a feeble rationalization of a prior commitment to authoritarianism.

The reason why this narrative does not add up is that the dispute between Hobbes and republicans is not about whether we should take an interest in non-arbitrary rule. It concerns two competing conceptions of non-arbitrariness, one relatively thin and formal, the other thicker and more substantive. A charitable reader of Leviathan will not find it difficult to reconstruct the reasons that led Hobbes to opt for the thin alternative. Hobbes feared that the pursuit of a thick and demanding ideal of

\footnotetext{
${ }^{63}$ See Pettit, Republicanism, 55-56.

64 See Skinner, Hobbes and Republican Liberty, 138-177.

65 See Pettit, 'Liberty and Leviathan', 146; Skinner, Hobbes and Republican Liberty, 151.

${ }^{66}$ See Skinner, Liberty Before Liberalism; Pettit, Republicanism, 17-50.
} 
non-domination that requires endless contestability would turn out to be incompatible with the existence of well-functioning political institutions capable of securing public order and social co-ordination. If that concern with institutional coherence is still relevant today, and it might well be, we should conclude that to have recovered the ideal of non-domination is not the same as to have successfully defended its most demanding version. Hobbes may well have been right that the scope of a feasible notion of non-domination is rather limited. And if that is the case, the neo-republican attempt to build a complete normative political theory on the notion of non-domination is likely to turn out to be ill-motivated. ${ }^{67}$

${ }^{67}$ See for a fuller development of this argument Vinx, 'Constitutional Indifferentism and Republican Freedom'. 